\title{
BENTENG AMSTERDAM DI PESISIR UTARA PULAU AMBON: Tinjauan Atas Aspek Kronologi dan Fungsi
}

\author{
Fort Amsterdam on the North Coast of Ambon Island: Examines the As- \\ pects of Chronology and Fuctions
}

\author{
Syahruddin Mansyur \\ Balai Arkeologi Ambon-Indonesia \\ Jl. Namalatu-Latuhalat, Nusaniwe, Ambon 97118 \\ hitam_putih07@yahoo.com
}

Naskah diterima: 09-03-2015; direvisi: 22-04-2015; disetujui: 25-05-2015

\begin{abstract}
Fort Amsterdam is one of the fort in the fortifications system that was built by the VOC since the 17th century in the Maluku Islands. This research examines the micro aspects in the fortification system by focusing on the aspects of the chronology as well as the functions and roles of Fort Amsterdam. The bibliographical studies and the use of historical records also adopted in this study. The reslut of this research shows the chronology of the first fort built in 1629 as a trading post by VOC in the North Coast region of the island of Ambon. This fort then undergoes renovations both aimed to strengthen the defense function as well as trade and government functions in this fort. Amsterdam role both during and future VOC Dutch East Indies governement policies related to the clove monopoly on the Colonial period. Period of receding role of the fort was then happended along with the moment of the abolition of the clove monopoly by the Dutch in 1865.
\end{abstract}

Keywords: Fort, Fortification System, Colonial, Ambon

\begin{abstract}
Abstrak
Benteng Amsterdam adalah salah satu benteng dalam sistem perbentengan yang dibangun oleh VOC sejak abad ke-17 di wilayah Kepulauan Maluku. Penelitian ini mengkaji aspek mikro dalam sistem perbentengan tersebut yaitu aspek kronologi serta aspek fungsi dan peran Benteng Amsterdam. Melalui kajian kepustakaan yang bersumber dari catatan-catatan historis, serta hasil penelitian terdahulu. Penelitian ini berhasil mengungkap kronologi benteng yang pertamakali dibangun pada tahun 1629 sebagai pos perdagangan VOC di wilayah Pesisir Utara Pulau Ambon. Benteng ini kemudian mengalami beberapakali renovasi yang bertujuan untuk memperkuat fungsi pertahanan serta fungsi perdagangan dan pemerintahan pada benteng ini. Peran Benteng Amsterdam pada masa VOC dan masa Pemerintah Hindia Belanda berhubungan dengan kebijakan monopoli cengkih pada masa Kolonial. Periode surut peran benteng ini kemudian mulai terjadi pada periode penghapusan monopoli cengkih oleh Belanda pada tahun 1865.
\end{abstract}

Kata Kunci: Benteng, Sistem Perbentengan, Kolonial, Ambon 


\section{PENDAHULUAN}

Benteng Amsterdam adalah salah satu tinggalan arkeologi yang monumental di Pulau Ambon. Benteng ini berada di wilayah pesisir utara Pulau Ambon atau yang dikenal dengan Jazirah Leihitu. Dalam historiografi lokal, wilayah ini dikenal pula sebagai pusat Kerajaan Tanah Hitu yang berkembang sekitar abad ke-15 hingga abad ke-17.

Kehadiran benteng Amsterdam ini menjadi penanda awal kehadiran bangsa Eropa di wilayah Maluku. Dalam catatan sejarah disebutkan bahwa wilayah ini merupakan salah satu wilayah yang telah melakukan kontak awal dengan bangsa Eropa. Sejak awal abad ke-16, para pedagang Portugis telah mendatangi wilayah ini dalam upaya penjelajahan mereka untuk menemukan sumber utama rempah-rempah khususnya cengkih dan pala. Keberhasilan Portugis pada tahun 1511 menguasai jalur perdagangan di Selat Malaka sebagai bandar transit komoditi rempah-rempah membuka jalan bagi mereka untuk menemukan Kepulauan Maluku. Kehadiran Portugis ini tercatat dalam kronik Hitu yang terkenal yaitu "Hikayat Tanah Hitu" yang ditulis oleh Imam Ridjali. Catatan Eropa sendiri menyebut bahwa kehadiran Portugis di Hitu terjadi pada tahun 1512. Setelah kedatangan bangsa Portugis, bangsa Eropa lain yang kemudian berhasil merebut hegemoni politik di wilayah ini adalah Belanda melalui badan usaha-nya yaitu Vereenigde Oostindische Compagnie (VOC). Catatan pertama kehadiran pedagang-pedagang Belanda di Jazirah Leihitu adalah kehadiran armada dagang Belanda di bawah pimpinan Jacob van Neck pada tahun 1599.

Sejak saat itu, Kepulauan Nusantara menjadi salah satu jalur pelayaran dan perdagangan global, karena pusat perdagangan rempah-rempah dan hasil bumi lainnya. Jaringan ini ditunjang oleh kondisi geografis, sumber alam, jaringan transportasi laut yang memudahkan pendistribusian hasil komoditi unggulannya, sehingga muncul bandar-bandar besar sebagai pelabuhan utama niaga, yang saling terkoneksi satu dengan yang lain. Sudah tentu dalam hal tataniaga rempah-rempah, antar wilayah tidak dapat dipisahkan dengan wilayah-wilayah lain yang saling terkait, berperan sebagai wilayah penyangga, penghasil, pendistribusi, ataupun pelabuhan singgah (Harkantiningsih, 2010: 1). Dengan demikian, selain terbentuk jaringan global yang menghubungkan Eropa dan Kepulauan Nusantara, juga terbentuk jaringan Nusantara sebagai bandar transit komoditi sebelum dibawa ke Eropa, serta jaringan lokal yang merupakan jalur untuk mengumpulkan komoditi.

Kondisi geografis Maluku yang terdiri atas pulau-pulau besar dan kecil, membentuk wilayah ini sebagai jaringan lokal yang terdiri atas pelabuhan-pelabuhan kecil untuk mengumpulkan komoditi cengkeh, salah satunya adalah pesisir utara Pulau Ambon atau Jazirah Leihitu. Setidaknya, berdasarkan data arkeologi berupa benteng yang tersebar di daerah ini menggambarkan hal tersebut. Terlebih, jika memperhatikan bentuk benteng yang sebagian besar berupa blokhuis yang memiliki bentuk menyerupai gudang atau loji. Dengan demikian, benteng memiliki fungsi ganda yaitu sebagai pusat pertahanan sekaligus sebagai gudang komoditi.

Salah satu benteng yang masuk dalam sistem perbentengan yang dibangun oleh VOC di Maluku adalah Benteng Amsterdam yang berada di Pulau Ambon. Adapun pemilihan lokasi didasarkan pada tiga alasan, yaitu; Pertama bahwa wilayah ini merupakan wilayah yang melakukan kontak awal dengan bangsa Eropa, kedua bahwa wilayah ini merupakan wilayah pertama yang melakukan kerjasama perdagangan (dalam konteks monopoli) dengan bangsa Eropa (Belanda), ketiga wilayah ini merupakan salah satu wilayah yang ditetapkan oleh VOC sebagai pusat produksi cengkih. Oleh karena itu, aspek yang dikaji dalam penelitian ini adalah; pertama, bagaimana 
variabilitas dan sebaran data arkeologi di lokasi penelitian; kedua, bagaimana kronologi benteng Amsterdam berdasarkan variabilitas temuannya?; ketiga, bagaimana fungsi dan peran benteng Amsterdam dalam konteks peran wilayah?.

Berdasarkan ketiga permasalahan tersebut, penelitian ini diharapkan dapat mengungkap dua aspek dalam mengkaji masa lalu, yaitu dimensi waktu dan dimensi ruang. Dimensi waktu berkaitan dengan sejak kapan benteng ini dibangun dan bagaimana rentang huniannya pada masa kolonial. Sementara dimensi ruang berkaitan dengan fungsi dan peran benteng dalam hubungannya dengan periode perdagangan masa kolonial. Terkait penelitian tentang dimensi waktu banteng-benteng colonial di Maluku, telah dilakukan sebelumnya di banteng Oranje yang ada di Ternate. Penelitian tersebut berhasil mengungkap bahwa penggunaan benteng Oranje berlangsung sejak abad ke-17 hingga awal abad ke-20, dimana faktor ekonomi dan politik menjadi pertimbangan utama penggunaan benteng (Inagurasi, 2011: 34).

Kehadiran bangsa Eropa di wilayah Nusantara didasari atas tujuan perdagangan. Pada awal kehadirannya sekitar abad ke16/17, mereka mendirikan loji-loji perdagangan (gudang) untuk menimbun barang dagangan berupa rempah-rempah dan sebagainya. Pembangunan loji-loji tersebut merupakan usaha awal bangsa Eropa untuk menguasai perdagangan rempah-rempah di Nusantara. Usaha untuk menguasai Nusantara semakin mantap dengan menjadikan loji-loji sebagai benteng pertahanan guna bersaing dengan pedagang-pedagang lain, sekaligus sebagai tempat tinggal (Soekiman, 1997:1-2). Bangunan benteng inilah kemudian menjadi pusat pengawasan terhadap daerah kekuasaannya. Selain itu, benteng juga menjadi kawasan permukiman yang berfungsi antara lain sebagai pusat pemerintahan, militer dan pertahanan bahkan ada juga yang berfungsi sebagai pusat perdagangan dan pelabuhan (Sumalyo, 1999:303).
Dalam konteks jaringan perdagangan khususnya pada periode kolonial di Maluku, sistem monopoli cengkih yang diterapkan oleh VOC berperan penting dalam keberhasilan mereka menguasai perdagangan rempah-rempah di Nusantara. Dalam konteks inipula, sistem monopoli ini didukung oleh sistem perbentengan yang kuat khususnya di wilayah Maluku. Sistem perbentengan ini tidak hanya berfungsi sebagai sistem pertahanan, sekaligus pula berfungsi sebagai sistem atau jaringan perdagangan dimana setiap benteng difungsikan sebagai pusat pengumpul komoditi (Mansyur, 2014: 96-97).

\section{METODE}

Sumber utama pengumpulan data berasal dari hasil penelitian yang dilakukan oleh Balai Arkeologi Ambon pada tahun 2012 dan tahun 2013. Penelitian yang dilakukan pada tahun 2012 adalah penelitian eksploratif dengan menggunakan metode observasi terhadap tinggalan pengaruh kolonial di wilayah pesisir utara Pulau Ambon. Sementara itu, penelitian tahun 2013 merupakan penelitian lanjutan dengan metode ekskavasi di Benteng Amsterdam. Dengan demikian, data penelitian tahun 2012 digunakan untuk mengetahui sebaran bangunan yang ada di banteng Amsterdam dan sekitarnya (Negeri Hila dan Negeri Kaitetu). Sementara itu, data penelitian tahun 2013 digunakan untuk mengetahui lebih detail tentang benteng Amsterdam termasuk dalam hal ini pembagian ruang dan bentuk-bentuk aktivitas yang ditemukan di bawah permukaan tanah (Tim Penelitian, 2012: 16-22), dan Tim Penelitian 2013: 17-27).

Selanjutnya, hasil dari kedua penelitian tersebut kemudian dielaborasi dan dianalisis lebih lanjut untuk menjawab permasalahan penelitian. Analisis kronologi digunakan untuk menjawab permasalahan yang berkaitan dengan dimensi waktu. Analisis ini difokuskan pada berbagai penafsiran terhadap data-data historis berupa dokumentasi yang menggambarkan benteng Amsterdam di masa lalu. Sementara itu, 
penafsiran-penafsiran terhadap data arkeologi difokuskan pada bukti-bukti aktivitas khususnya temuan keramik asing di permukaan tanah dan di bawah permukaan tanah. Sementara itu, analisis keruangan digunakan untuk menjawab dimensi ruang. Analisis ini difokuskan pada berbagai penafsiran terhadap data historis maupun data arkeologi berupa jejak-jejak pembagian ruang yang masih dapat diamati di benteng Amsterdam.

\section{HASIL DAN PEMBAHASAN \\ Catatan Historis Kontak Awal Bangsa Eropa di Wilayah Pesisir Utara Pulau Ambon}

Dalam historiografi lokal, wilayah pesisir utara Pulau Ambon atau Jazirah Leihitu pernah berkembang menjadi satu kerajaan yang dikenal dengan Kerajaan Tanah Hitu. Sejarah terbentuknya kerajaan ini menunjukkan bahwa wilayah ini telah melakukan kontak dengan dunia luar baik dari wilayah Kepulauan Maluku maupun wilayah nusantara bagian barat. Hikayat Tanah Hitu yang ditulis oleh Imam Ridjali, menjelaskan bahwa para pendiri Kerajaan Tanah Hitu adalah orang-orang asli pulau ini serta orang-orang yang datang dari $\mathrm{Pu}-$ lau Seram, Gorom, Jailolo, dan Jawa (de Graaf, 1977: 15). Demikian halnya pada masa awal berkembangnya agama Islam di wilayah ini dimana salah satu Raja dari Tanah Hitu yaitu Pati Tuban belajar agama Islam di Tanah Jawa bersama-sama dengan Sultan Zainal Abidin dari Ternate. Bahkan jauh sebelumnya, wilayah ini telah melakukan kontak dengan Kerajaan Majapahit di Tanah Jawa, dimana dalam Kitab Negarakertagama disebutkan bahwa salah satu wilayah yang telah melakukan kontak dengan Majapahit adalah "Ambwan" atau Ambon $^{1}$. Bahkan menurut Imam Rijali, tanpa

1 Hubungan antara Kepulauan Maluku dan Tanah Jawa juga tercermin dari beberapa toponim yang masih dikenal hingga saat ini yaitu, di Pulau Buru terdapat suatu tempat yang disebut Masapait, di Pulau Manipa terdapat nama tempat Tuban, di Hitu sendiri dikenal sungai Masapait, serta di Loki di Pulau Seram terdapat sungai yang disebut dengan Sungai Palapa. menyebut lokasinya, terdapat permukiman orang-orang Jawa di salah satu perkampunan di Jazirah Leihitu ${ }^{2}$ (Leirissa, 1973: 4). Hubungan dengan dunia luar inilah yang kemudian menjadi cikal bakal terbukanya jalur pelayaran bagi bangsa Eropa ke wilayah Kepulauan Maluku.

Dimulai dengan kehadiran bangsa Portugis, sebagaimana dikisahkan oleh Imam Ridjali dalam Hikayat Tanah Hitu, pada masa Perdana Jamilu menjadi penguasa di Tanah Hitu sebuah peristiwa karamnya kapal asing di "Puluh Tiga/Nusa Telu" atau Pulau Tiga ${ }^{3}$. Dalam hikayat tersebut dikisahkan pula ciri-ciri orang asing yang terdampar di Pulau Tiga serta percakapan tentang asal usul mereka :

..... Alkissah dan kuceriterakan yang empunya ceritera: sekali perastawa sebua perau Saki Besi Nusatelu* ke laut Puluh Tiga mengambil ikan. Maka ia datang membawah khabar kepada perdana Jamilu, demikian katanya: 'Ada kami bertemu sebua perau di laut Puluh Tiga. Selamanya umur kami hidup dalam dunia, bulum lagi melihat rupa manusyia bagai rupa orang itu. Tubuhnya putih dan matanya seperti mata kucing. Lalu kami tanya kepadanya, ia tiada tahu bahasa kami dan kami pun tiada tahu bangsyanya.' Maka kata perdana Jamilu: 'Pergilah engkau bawah ia ke mari.' Maka kembali pula bawah ia datang ke negeri kepada perdana Jamilu. Lalu ditanya kepadanya: 'Darimana datang dan apa nama negerimu?' Maka ia menyahut: 'Ada pun kami ini datang di sini kami sessat tiada tahu jalan. Maka kami jatuh pesir* ke tanah sebelah dan kapal kami pun tekarang di laut Puluh Burung*. Maka tinggal kapal kami, naik kepada sampang endak pulang ke negeri Portugal.

(Hikayat Tanah Hitu: www.amalatu.zoomshare.com)

2 Sangat mungkin yang dimaksudkan adalah "Kota Jawa" salah satu perkampungan yang terletak di pesisir selatan Jazirah Leihitu.

3 Sementara itu, Rumphius menyebut peristiwa terdamparnya armada Serrao di kepulauan Nussapinyo atau Pulau Penyu (arah selatan Pulau Ambon). 
Sementara itu, Paramitha R. Abdurachman (2008), menyebut bahwa Portugis mulai muncul di perairan Banda dan Ambon pada tahun 1512. Namun, karena pengaruh politik Ternate serta persaingan dengan Kesultanan Tidore, maka Sultan Ternate mengutus adiknya Kasis Kaichil Vaidus untuk mengundang orang-orang asing ini menetap di Ternate. Orang-orang Portugis yang terdampar di Tanah Hitu ini merupakan wakil penguasa Portugis yang dikirim dari Malaka untuk pencarian Kepulauan Rempah, di bawah pimpinan Antonio Albreu dan Francisco Serrao ${ }^{4}$. Hal mana kemudian, Portugis memutuskan untuk memusatkan aktivitas perdagangan dan politik mereka dengan membangun benteng di Ternate pada tahun 1522 (Abdurachman, 2008: 98 dan Ricklefs, 2010: 45). Hubungan antara Tanah Hitu dan Portugis kemudian tidak lepas dari pengaruh politik Ternate saat itu.

Meski Portugis memilih Ternate sebagai pusat pemerintahan dan perdagangan, namun Portugis tetap menganggap wilayah Tanah Hitu sebagai wilayah yang strategis. Hal ini tampak pada pembangunan sebuah loji sejak tahun 1515, sebagai tempat persinggahan bagi frotilla Portugis yang berlayar ke Kepulauan Maluku (Abdurrachman, 2008: 124). Posisi strategis Hitu sendiri bagi Portugis tidak lepas dari jalur perdagangan rempah-rempah di Maluku yang menghubungkan Kepulauan Banda (yang terletak di sebelah tenggara Hitu) sebagai sumber utama pala dan Ternate (utara Hitu) sebagai sumber utama cengkih. Disebutkan pula oleh Rumphius, bahwa armada Portugis yang pertamakali mengunjungi wilayah Maluku membuat laporan lengkap perjalanan mereka dan menyebut tentang peristiwa terdamparnya Fransisco Serrao di perairan Maluku yang kemudian mendapat pertolongan dari orang-orang Hitu. Berdasarkan laporan inilah, armada Portugis yang datang ke Maluku (Ternate dan Banda)

4 Sumber lain dari Rumphius menyebut bahwa Fransisco Serrao bukanlah orang Eropa pertama yang datang ke wilayah Maluku melainkan rombongan yang dipimpin oleh Ludovicus Vartomannus yang tiba pada tahun 1506 (Manusama, 1973: 30). juga singgah di Hitu (Rumphius, tanpa tahun: $3)$.

Pengaruh lain kehadiran bangsa Portugis yang memposisikan Tanah Hitu sebagai wilayah yang strategis tampak pada pemberian gelar Kapitan Tanah Hitu. Perdana Jamilu sendiri pada saat itu merupakan pimpinan Empat Perdana Kerajaan Tanah Hitu. Perdana Jamilu bahkan memperoleh gelar lain yaitu "Don" dari Raja Portugal sebagai tanda penghormatan dan terimakasih atas pelayanan yang diberikan kepada armada Portugis di bawah pimpinan Serrao (Manusama, 1973: 30-31). Hubungan baik inilah yang kemudian melatari pemberian ijin oleh Kerajaan Tanah Hitu kepada orang-orang Portugis untuk mendirikan loji di Jazirah Leihitu. Dalam perkembangan selanjutnya, selain mendirikan sebuah loji, orang-orang Portugis juga membentuk permukiman di ujung barat Jazirah Leihitu. Hal ini dapat diketahui berdasarkan sejarah toponim yaitu Sawahtelu yang berarti "tiga sawah" yang berada di daerah pesisir Negeri Morela. Sawahtelu sendiri merupakan daerah perkebunan bagi komunitas orang-orang Portugis di Tanah Hitu (Abdurachman, 1973: 46; Abdurachman, 2008: 115).

Dalam periode-periode berikutnya, hubungan antara Hitu dan Portugis mengalami kemunduran seiring dengan penolakan pihak penguasa Hitu yang notabene merupakan kerajaan Islam terhadap usaha-usaha penginjilan yang dilakukan oleh orang-orang Portugis. Penolakan ini mencapai puncaknya pada tahun 1538 , dimana orang-orang Portugis diusir dari loji mereka yang ada di pantai utara. Orang-orang Portugis kemudian memilih untuk menyingkir ke pesisir selatan di Teluk Dalam (Teluk Ambon) untuk mendirikan perkampungan yang hingga saat ini disebut dengan Poka. Kemudian berpindah lagi ke suatu tempat dekat sebuah tanjung yang diberi nama Cabo Martim Affonso atau Tanjung Martafons. Perkampungan ini pun kemudian ditinggalkan hingga akhirnya Portugis membangun sebuah benteng lebih kuat di Jazirah Leitimor yang selesai dibangun pada Juni 1576 (Abdurachman, 2008: 129). 
Hubungan antara Hitu dan Portugis mengalami kemunduran sejak pertengahan abad ke-16 hingga mencapai puncaknya pada tahun 1570 . Gelombang serangan yang dilakukan oleh pihak Hitu diantaranya tahun 1558, 1565, 1570 dan 1599-1600. Dalam periode perang antara Hitu dan Portugis, pihak Hitu mendapat bantuan dari Kimelaha Lautaka (Banda ?) tahun 1558, Raja Giri tahun 1565, Ternate tahun 1570, serta Luhu, Buru dan Belanda tahun 1599-1600. Namun, serangan-serangan yang dilancarkan oleh pihak Hitu tidak berhasil melumpuhkan kekuatan Portugis yang berpusat di Leitimor, bahkan beberapakali pihak Portugis berhasil melakukan serangan balik terhadap kekuatan Hitu. Serangan terakhir yang dilancarkan oleh pihak Hitu menyebabkan kemarahan pihak Portugis yang kemudian menyerang kedudukan Hitu di pesisir Kaitetu, dimana sebelumnya pihak Hitu telah mengijinkan pedagang-pedagang Belanda untuk membangun sebuah benteng di wilayah ini. Kehadiran Belanda sebagai kekuatan baru di Maluku disadari oleh Portugis sebagai pesaing utama. Oleh karena itu, Portugis mendatangkan armada baru di bawah pimpinan Andrea Furtado pada tahun 1602 guna membendung kehadiran pihak Belanda di Maluku (Rumphius, tanpa tahun: 6-11).

Keadaan politik antara Hitu dan Portugis yang penuh gejolak tidak berlangsung lama sejak kehadiran ekspedisi-ekspedisi dagang Belanda. Kehadiran Belanda tahun 1599 dan Inggris pada tahun 1604 sebagai kekuatan baru meningkatkan persaingan diantara bangsa-bangsa Eropa menguasai perdagangan rempah-rempah di wilayah ini. Pedagang-pedagang Belanda yang membentuk badan usaha pada tahun 1602 , kemudian berhasil memanfaatkan situasi politik antara Hitu dan Portugis.

Sementara itu, awal kedatangan orang-orang Belanda ke wilayah Nusantara terjadi pada tahun 1596, untuk memperoleh rempah-rempah yang saat itu menjadi komoditi utama perdagangan dunia. Oleh karena itu, tujuan utama mereka adalah ban- dar perdagangan rempah-rempah Nusantara yaitu di Pelabuhan Banten. Kehadiran Portugis lebih awal yang telah menguasai jalur perdagangan di Selat Malaka sekaligus menyebabkan Belanda lebih memilih Banten pada saat itu. Selanjutnya, ekspedisi pertama pedagang-pedagang Belanda ini kemudian kembali ke Belanda pada tahun 1597 dengan membawa rempah-rempah yang cukup banyak (Ricklefs, 2010: 50).

Ekspedisi para pedagang Belanda selanjutnya kemudian berhasil tiba di Kepulauan Rempah-Rempah pada tahun 1599. Ekspedisi ini di pimpinan oleh Jacob van Neck yang berhasil menjalin hubungan perdagangan dengan Hitu. Selain itu, ekspedisi ini juga mengunjungi Kepulauan Banda dan berhasil pula menjalin hubungan perdagangan di sana. Ekspedisi inilah yang berhasil membawa sejumlah rempah-rempah dengan keuntungan yang mencapai 400 persen (Ricklefs, 2010: 51). Pada kunjungan berikutnya, tahun 1600, Belanda berhasil meyakinkan pihak Hitu untuk melakukan kerjasama perdagangan serta sepakat memerangi Portugis yang saat itu menjadikan wilayah Leitimor (jasirah selatan Pulau Ambon) sebagai pusat kekuasaan. Pihak Hitu kemudian memberi izin pembangunan sebuah benteng di tempat berbatu karang yang bernama "Hatunuku" untuk Belanda. Benteng ini diberi nama "Kasteel van Verre" atau "Kota Warwijk", benteng ini sendiri merupakan benteng Belanda pertama yang ada di Asia (Bonke, 2010: 34). Dalam perjanjian ini disebutkan pula, bahwa pihak Hitu harus menjual seluruh hasil panen cengkih kepada Belanda dengan harga yang telah disepakati. Peristiwa inilah yang menjadi tonggak awal Belanda dalam melakukan kontrak dagang tentang monopoli cengkih di Maluku serta untuk pertamakalinya mengibarkan bendera triwarna di Nusantara (de Graaf, 1977: 71).

Keberhasilan ekspedisi-ekspedisi ini kemudian menjadi titik awal Belanda untuk menguasai perdagangan rempah-rempah di Nusantara. Keuntungan dari ekspedisi ini 
pula yang kemudian menjadi pertimbangan utama pedagang Belanda untuk mendirikan badan usaha yang disebut Vereenigde Oostindische Compagnie atau VOC pada tanggal 20 Maret 1602 (Ricklefs, 2010: 51).

Pendirian badan usaha ini sebenarnya telah diusulkan sejak tahun 1598 oleh Parlemen Belanda karena meningkatnya persaingan diantara perseroan-perseroan yang telah membiayai ekspedisi-ekspedisi pelayaran khususnya ke wilayah sumber rempah-rempah. Usulan ini kemudian diterima oleh keempat wakil dagang Belanda pada tahun 1602. Selain keuntungan besar yang diperoleh pada ekspedisi-ekspedisi sebelumnya, usulan untuk mendirikan suatu badan usaha dimaksudkan untuk menghadapi persaingan diantara badan usaha lain yang juga didirikan oleh pedagang-pedagang Eropa lainnya. Sejak periode awal kedatangan ekspedisi Belanda tahun 1598 yang berhasil membawa keuntungan besar, maka empat belas buah ekspedisi yang berbeda diberangkatkan dari Belanda ke wilayah Nusantara pada tahun 1601 (Ricklefs, 2010: 51).

Situasi politik antara Hitu dengan Portugis yang memanas sejak peristiwa terbunuhnya Sultan Hairun di Kesultanan Ternate menjadi keuntungan tersendiri bagi VOC yang baru terbentuk. Bantuan VOC terhadap Hitu dalam perang melawan Portugis menjadi dalih bagi mereka untuk memperoleh keuntungan secara politis. Sejak terbunuhnya Sultan Hairun pada tahun 1570, Portugis memindahkan pusat kekuasaannya dari Ternate ke Pulau Ambon. Hal ini sekaligus menyebabkan konflik antara Hitu dan Portugis semakin sering terjadi. Serangan terhadap kedudukan Portugis di Pulau Ambon terjadi pada tahun 1600, dimana pihak Hitu mendapat bantuan dari Jepara. Kedudukan Portugis di Ambon kemudian jatuh pada tahun 1605 dalam sebuah serangan yang dipimpin oleh pihak VOC dan merebut kekuasaan dari Portugis.

Keberhasilan VOC merebut kekuasaan Portugis atas Pulau Ambon yang kemudian menjadikan wilayah ini sebagai pusat pemerintahan dari tahun 1610-1619 yang berkedudukan di bekas benteng Portugis (Ricklefs, 2010: 52-54). Keberhasilan ini sekaligus berdampak pada situasi politik kewilayahan di Pulau Ambon, dimana VOC menempatkan pusat pemerintahannya di wilayah Leitimor dan hanya menempatkan perwakilan pos perdagangan di Hila sebagai pusat administrasi perdagangan untuk wilayah pesisir utara Pulau Ambon.

\section{Benteng Amsterdam dan Sebaran Data Arkeologi di Wilayah Hila-Kaitetu}

\section{Deskripsi Benteng Amsterdam}

Pembahasan ini menguraikan secara deskriptif Benteng Amsterdam berdasarkan aspek rancang bangun, pembagian ruangan dan data artefaktualnya. Pembahasan tentang rancang bangun menguraikan bentuk umum atau bangunan utama yang terdapat di Benteng Amsterdam. Pembahasan tentang pembagian ruangan selain mengurai secara deskriptif tentang sisa struktur yang masih dapat diamati juga berusaha melakukan interpretasi tentang fungsi dan kegunaan masing-masing ruangan yang ada di dalam kompleks Benteng Amsterdam.

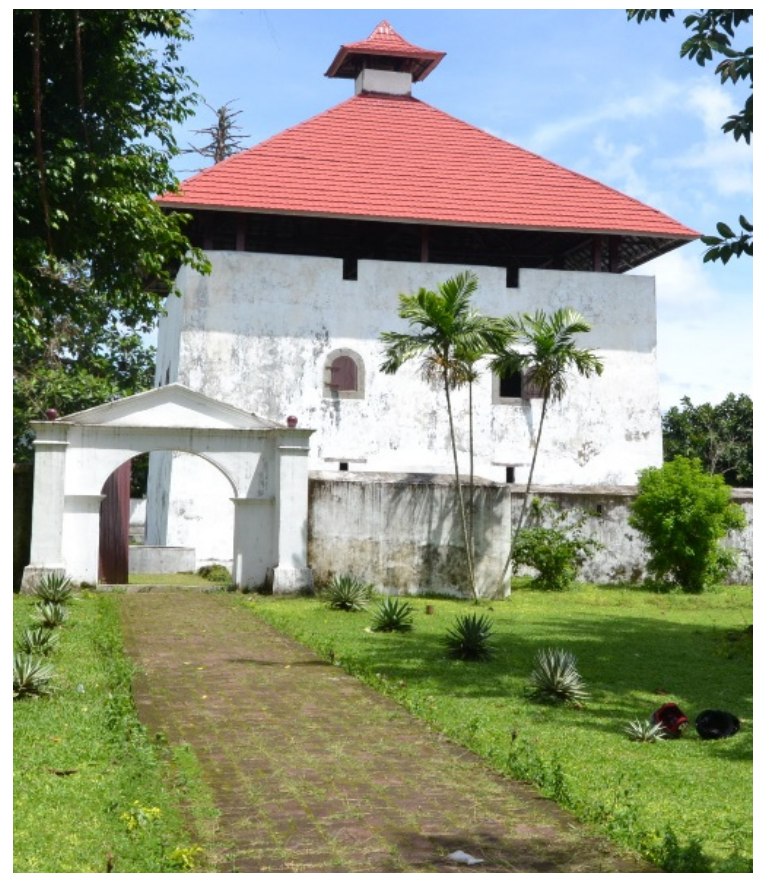

Gambar 1. Tampak Depan Benteng Amsterdam (Sumber: Dokumen Balai Arkeologi Maluku, 2012) 
Rancang Bangun. Benteng Amsterdam terletak antara Negeri Hila dan Negeri Kaitetu, bangunan benteng ini berada di tepi pantai dan bersebelahan dengan Gereja Tua Hila. Benteng ini merupakan bangunan dengan tipe Blokhuis yaitu bangunan benteng dengan bentuk yang menjulang tinggi. Denah dasar benteng berbentuk persegi dengan ukuran \pm 10 x 10 meter, dan bagian dalam terbagi atas tiga lantai. Lantai pertama terbagi atas dua ruang yaitu ruang tengah dengan ukuran yang lebih luas sementara sebuah ruangan kecil terdapat pada sisi depan yaitu sebelah kiri pintu masuk. Tangga menuju ke lantai kedua terdapat di sisi kanan pintu masuk, dan lantai kedua tidak memiliki pemisahan ruang. Lantai ketiga merupakan lantai terakhir, bagian ini merupakan area yang cukup terbuka karena dinding bangunan tidak tertutup hingga bagian atap. Pada bagian ini pula terdapat embrasure atau tempat mendudukkan meriam pada setiap sudut. Bagian dasar pada lantai kedua dan ketiga merupakan lantai yang terbuat dari papan kayu yang disusun sedemikian rupa. Pada lantai kedua terdapat sebuah balkon di sisi bangunan yang menghadap ke laut. Jika mengamati kondisi bangunan benteng ini, tampak bahwa setiap ruangan atau lantai memiliki fungsi masingmasing yaitu lantai pertama sebagai gudang, lantai kedua merupakan ruangan bagi para petugas dan lantai ketiga berfungsi sebagai tempat pengintaian. Adapun ruangan kecil yang terdapat di sisi kiri pintu masuk pada lantai pertama berfungsi sebagai ruang tahanan. Selain bangunan utama berbentuk Blokhuis, bangunan ini dikelilingi dinding setebal \pm 2 meter dengan tambahan bastion.

Secara umum, Benteng Amsterdam terbagi atas dua bagian yaitu bangunan utama berupa Blokhuis yaitu bangunan yang menjulang ke atas dengan denah dasar berbentuk persegi. Bagian kedua berupa halaman yang luas di luar bangunan utama yang dikelilingi oleh courtien (dinding benteng) dan dua bastioan setinggi \pm 3 meter. Pada bagian kedua inilah tampak beberapa sisa struktur pondasi dan beberapa bagian lantai atau dasar bangunan. Sisa struktur ini tampak menyatu dengan sisi dinding selatan dan timur benteng. Jika diamati lebih lanjut, kedua sisi dinding ini merupakan akses ke luar benteng yaitu sisi timur merupakan gerbang utama, dan sisi selatan merupakan pintu samping benteng. Detail sisa struktur ini menampakkan secara jelas pembagian ruangan di dalam kompleks Benteng Amsterdam. Pembahasan lebih lengkap tentang sisa struktur pembagian ruangan dapat dilihat pada uraian selanjutnya.

Pembagian Ruangan. Penelitian yang dilakukan pada tahun 2013 berhasil menyingkap beberapa sisa struktur yang terdapat pada permukaan tanah di dalam kompleks benteng Amsterdam. Keberadaan sisa struktur di dalam lokasi benteng memberi indikasi adanya pembagian fungsi ruang Benteng Amsterdam. Sebagaimana hasil penyingkapan struktur yang berada di dalam benteng diketahui beberapa ruang atau bangunan yang menempel di sisi dinding yaitu dinding timur dan selatan. Sisi dinding timur merupakan bagian depan sehingga struktur bangunan yang ada menyatu dengan pintu gerbang. Sementara itu, struktur yang menempel di sisi selatan merupakan akses menuju ke arah selatan yang menjadi satu-satunya arah akses untuk pengembangan fungsi ruang hal ini, karena sebelah utara dan barat merupakan sisi yang berbatasan langsung dengan pantai.

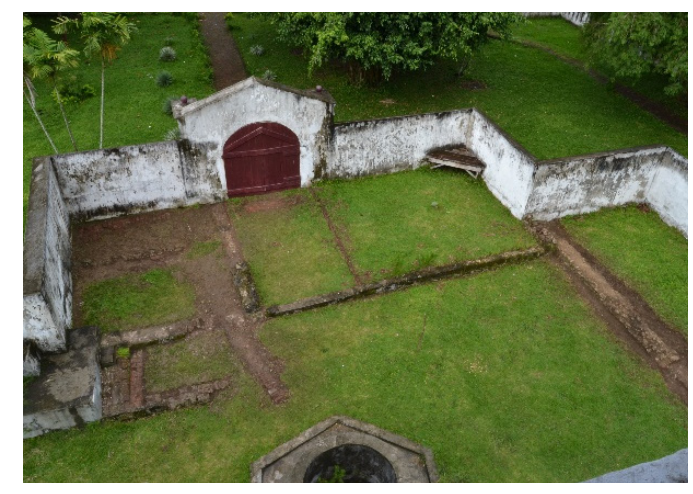

Gambar 2. Tampak sisa struktur yang terdapat di bagian depan kompleks Benteng Amsterdam.

(Sumber: Dokumen Balai Arkeologi Maluku, 2013) 
Uraian tentang pembagian ruangan berikut ini pertama-tama membahas tentang deskripsi masing-masing sisa struktur yang dapat diamati. Selanjutnya dibahas tentang fungsi dan kegunaan masing-masing ruangan.

Sisa struktur yang berada di sisi timur tampak menyatu dengan pintu gerbang benteng. Adapun pembagian ruang yang tampak di sisi ini adalah tiga ruang yaitu dua ruang di sisi sebelah utara dan satu ruang di sebelah timur. Meski terlihat secara umum hanya terbagi atas dua ruang, namun keberadaan pondasi dinding pemisah arah utara-selatan sehingga ruang ini terbagi dua (ruang timur dan barat). Jika mengamati sisa struktur pondasi masing-masing ruang, terdapat bekas umpak pintu pada setiap dinding. Bekas umpak yang terdapat pada dua ruang yang berada di sisi utara tampak jelas memperlihatkan penyatuan pintu masuk ke dua ruangan ini karena bekas umpak terletak di depan dinding pemisah ke dua ruangan ini (ruang timur dan barat). Sementara itu, di ruang barat masih terdapat bekas umpak di dinding barat yang merupakan akses terdekat menuju ke pintu masuk Blokhuis termasuk akses menuju ke sebuah sumur yang terdapat di tengah-tengah benteng. Ruangan selanjutnya, sebuah ruangan berbentuk persegi panjang arah utara-selatan yang berada di sisi selatan dan memiliki ukuran lebih besar dari dua ruangan yang ada di sisi utara. Bekas umpak juga terdapat di struktur pondasi yaitu pada pondasi barat dan timur. Jika diamati kedua umpak yang terdapat di sisi barat sejajar dengan pintu masuk benteng. Dengan demikian, sebagaimana konstruksi benteng pada umumnya, bagian yang sejajar antara pintu benteng dan bekas umpak sekaligus merupakan selasar atau pintu terowongan menuju ke dalam benteng.

Sisa struktur berikutnya terdapat di sisi selatan dan menempel pada dinding selatan benteng. Sisa struktur yang tampak dari hasil pengupasan memperlihatkan bahwa struktur ini merupakan dua bangunan utama yang terpisah yaitu bangunan yang berada di sisi timur dan barat. Bangunan yang berada di sisi timur merupakan bangunan yang lebih besar dengan bentuk persegi panjang arah timur-barat. Sementara bangunan yang berada di sisi barat terbagi atas tiga ruangan. Adapun bekas umpak pada bangunan yang berada di sisi timur memperlihatkan bahwa pintu masuk berada tepat di tengah-tengah sisi dinding utara.

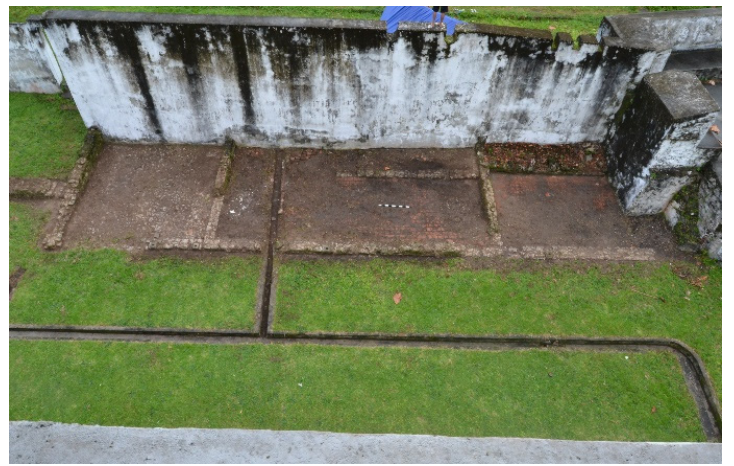

Gambar 3. Tampak sisa struktur yang terdapat di bagian samping (timur) kompleks Benteng Amsterdam

(Sumber: Dokumen Balai Arkeologi Maluku, 2013)

Bangunan kedua yang terbagi atas tiga ruang berada di sisi barat, dan ketiganya memiliki pintu masuk pada sisi dinding utara. Ketiga ruangan ini memiliki ukuran yang berbeda-beda, dimana ruang tengah merupakan ruangan paling besar. Bangunan ini juga dilengkapi dengan saluran air yang menghubungkan bagian dalam dan luar ruangan (sebelah utara). Ruangan yang terhubung oleh saluran air ini adalah ruangan yang paling besar atau ruang tengah. Pada ruangan ini juga terdapat struktur pondasi di sisi selatan ruangan dekat dengan dinding selatan. Sementara ruangan ketiga merupakan ruangan terakhir yang berada di sisi barat. Ruangan terakhir ini juga terdapat struktur pondasi di sisi selatan ruangan dekat dengan dinding selatan.

Berkaitan dengan fungsi ruang yang berada di dalam lokasi benteng dapat diuraikan berikut ini. Ruangan yang menempel pada sisi dinding timur benteng merupakan ruang depan dimana dua ruangan di sebelah utara atau sisi kiri pintu masuk merupakan 
ruangan khusus yang berfungsi sebagai pos penjagaan. Sementara ruangan yang berada di sebelah selatan atau sisi kanan pintu masuk tampaknya berfungsi sebagai kantor. Adapun bangunan yang berada di sisi selatan benteng berfungsi sebagai tempat tinggal bagi petugas yang berkaitan dengan fungsi militer atau fungsi administrasi pemerintahan Kolonial yang dipusatkan di wilayah Leihitu. Dan fungsi ketiga ruangan pada bangunan yang berada di sisi barat berfungsi sebagai tempat tinggal, kamar mandi dan dapur. Ruangan yang berada di sisi timur merupakan kamar (tempat tinggal). Sementara, jika mengamati keberadaan saluran air dan struktur pondasi pada ruang tengah, diduga ruangan ini berfungsi sebagai kamar mandi. Sementara ruangan ketiga berfungsi sebagai dapur, hal ini tampak jelas pada sisi dinding timur ruangan yang berwarna hitam yang menunjukkan sisa pembakaran yang menempel pada dinding ruangan.

Pada perkembangan selanjutnya, pemanfaatan fungsi ruang di kawasan Benteng Amsterdam dan sekitarnya kemudian mengarah ke selatan benteng. Hal ini jika mengamati sisa struktur maupun bangunan yang masih ada di sekitar lokasi benteng. Struktur yang masih dapat diamati diantaranya struktur pondasi yang tidak jauh $( \pm$ 5 meter) di sebelah selatan benteng. Indikasi arah perkembangan permukiman di kawasan ini tampak pada keberadaan sumur ( \pm 100 meter arah barat daya), gereja ( \pm 150 meter arah tenggara), dan kerkhof ( \pm 300 meter arah tenggara).

Data Artefaktual. Penelitian yang dilakukan pada tahun 2013 juga berhasil memperoleh data vertikal atau artefaktual di benteng Amsterdam. Beberapa artefak yang berhasil ditemukan di Benteng Amsterdam berupa fragmen gerabah, keramik, stoneware, bata, genteng, struktur lepas, besi, kaca, pipa tembakau, batu tulis, tulang, gigi, dan kerang.

Fragmen gerabah merupakan jenis temuan paling dominan baik dari sisi jumlah mau- pun persebarannya. Secara umum, bentuk gerabah berdasarkan analisis tipologi dapat dikelompokkan ke dalam bentuk berupa piring, mangkuk, tempayan dan kendi. Sementara itu, fragmen keramik merupakan jenis temuan terbanyak kedua yang berhasil dikumpulkan dalam penelitian ini. Sebagian besar merupakan keramik yang berasal dari Cina, Eropa dan Vietnam. Berdasarkan analisis kronologinya, fragmen keramik yang paling tua diduga berasal dari Dinasti Ming yaitu abad ke 16/17, selanjutnya adalah keramik dari Dinasti Qing yaitu abad ke $17-20$, serta keramik yang berasal dari Eropa yaitu abad ke 19-20. Sementara itu, keramik paling dominan adalah keramik yang berasal dari Dinasti Qing yaitu abad ke 17 - 20 (Tim Penelitian, 2013: 35).
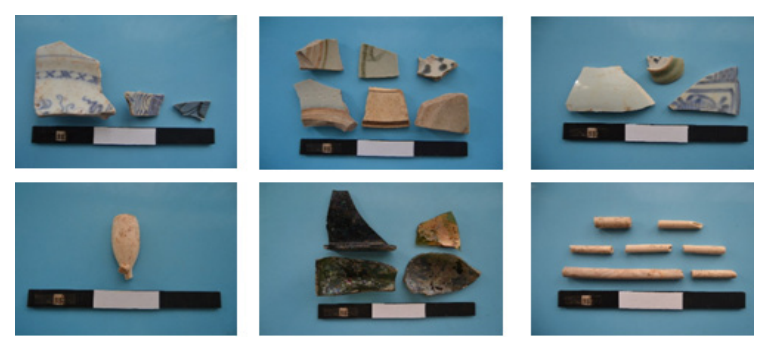

Gambar 4,5,6,7,8, dan 9. Ragam temuan yang ditemukan dalam kegiatan ekskavasi di Situs Benteng Amsterdam.

(Sumber: Dokumen Balai Arkeologi Maluku, 2013)

\section{Gereja Tua Hila}

Tepat di sebelah selatan Benteng Amsterdam terdapat Gereja Tua Hila. Saat ini, bangunan gereja merupakan bangunan baru yang pembangunannya diprakarsai oleh masyarakat muslim di Jazirah Leihitu dan bekerjasama dengan Pemerintah Provinsi Maluku pada tahun 2009. Bangunan yang ada saat ini memiliki konstruksi utama yang sebagian besar terbuat dari kayu. Pada bagian pondasi terbuat dari tembok setinggi \pm 1 meter yang kemudian ditambahkan dengan susunan papan kayu secara vertikal pada bagian atas hingga mencapai bagian atap. Bahan kayu juga digunakan pada bagian langit-langit yang tampak pada bagian dalam bangunan. Sementara itu, konstruksi atap juga menggu- 
nakan balok-balok kayu kemudian bagian atap sendiri merupakan atap daun rumbia. Pada bagian dalam, masih tampak sisasisa bangunan sebelumnya yaitu beberapa ubin berwarna cokelat kemerahan yang dipasang di bagian lantai. Bangunan ini dilengkapi dengan beberapa elemen pintu dan jendela, pintu yang merupakan satusatunya pintu masuk terdapat di sisi utara bagian depan bangunan dan dilengkapi dengan tiga jendela pada dinding timur dan barat, sementara pada dinding selatan terdapat dua jendela dan pada dinding bagian utara terdapat empat jendela. Bentuk umum jendela yang terdapat pada sisi timur, barat dan selatan yaitu bentuk persegi pada sisi bawah dan bentuk melingkar pada sisi bagian atas. Jendela pada sisi dinding utara berbentuk segi empat. Saat ini, bagian dalam bangunan juga dilengkapi dengan mimbar serta beberapa bangku.

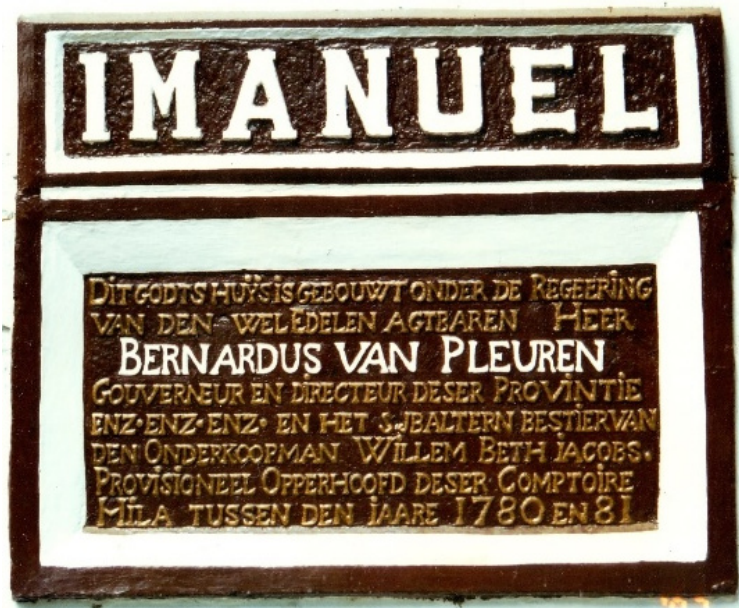

Gambar 10: Prasasti pembangunan Gereja Imanuel di Hila

(Sumber: Tim Penelitian Balai Arkeologi Ambon, 1997)

Berdasarkan dokumentasi hasil penelitian yang dimiliki oleh Balai Arkeologi Ambon pada tahun 1997 terdapat sebuah foto prasasti bangunan gereja yang memuat keterangan bahwa gereja ini bernama Gereja Imanuel yang dibangun pada tahun 1780 yaitu pada masa pemerintahan Gubernur Amboina Bernardus Van Pleuren dan Willem Beth Jacobs menjabat sebagai Comptoir Hila.

\section{Rumah dan Masjid Hasan Soleman}

Bangunan lain yang memiliki ciri arsitektur kolonial yang terdapat di wilayah ini adalah Rumah Hasan Soleman dan Masjid Hasan Soleman atau yang saat ini dikenal dengan Masjid Besar Al-Mukhsinin Hila. Kedua bangunan ini terdapat di wilayah administratif Negeri Hila. Hasan Soleman merupakan tokoh masyakat Hitu pada masa awal pemerintahan VOC di Ambon. Dia dikenal sebagai salah seorang pedagang dan menjadi Raja di Negeri Hila sejak akhir abad ke-17.

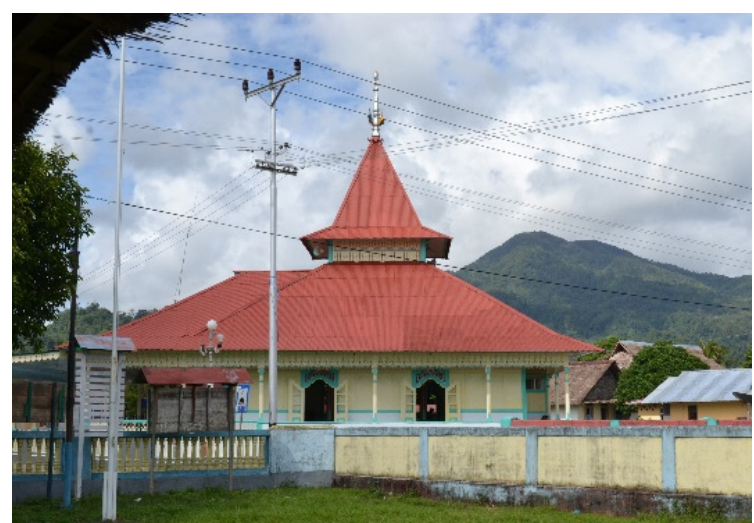

Gambar 11: Tampak depan Masjid Hasan di Hila (Sumber: Tim Penelitian Balai Arkeologi Ambon, 2002)

Masjid Hasan Soleman dibangun pertamakali sekitar tahun 1700-an dan pada tahun 1816 dibangun kembali dengan struktur yang permanen sebagaimana kondisi saat ini. Ciri utama bangunan kolonial yang tampak adalah ketebalan dinding pondasi bangunan masjid. Konstruksi utama bangunan masjid ini terdiri atas tiga bagian utama yaitu bagian dasar atau lantai, badan atau dinding dan bagian atas yang merupakan atap bangunan. Denah dasar bangunan ini terbagi atas dua, selain ruang dalam sebagai ruang utama atau ruang ibadah, bangunan ini dikelilingi dengan teras pada bagian luar dimana sisi paling luas adalah sisi timur sebagai pintu masuk. Elemen utama pada bangunan ini merupakan perpaduan pondasi tembok dengan tinggi \pm 1 meter, kemudian pada bagian atas yang merupakan dinding bangunan terbuat dari papan kayu. Susunan 
papan kayu ini cukup unik dimana setiap rangka balok kayu disusun sedemikian rupa secara vertikal dan horizontal, papan-papan kayu kemudian disusun secara diagonal pada sisi rangka balok kayu sehingga membentuk huruf "Y". Pada bagian atas pintu dan jendela bangunan terdapat ukiran kayu dengan motif hias flora. Langit-langit pada bagian luar bangunan terdapat hiasan papan kayu yang disusun mengelilingi bangunan masjid.

\section{Kerkhof}

Selain bangunan arsitektural, temuan lain yang ada di Hila adalah kompleks makam atau Kerkhof yang berjarak sekitar $\pm 200 \mathrm{~m}$ di sebelah selatan Benteng Amsterdam dan Gereja Tua Hila. Lokasi kerkhof ini juga dekat dengan Masjid Tua Wapauwe yaitu \pm 150 $\mathrm{m}$ sebelah timur lokasi masjid. Kondisi kompleks makam saat ini tidak terawat, namun masih dapat diamati beberapa makam yang ada di lokasi ini. Terdapat

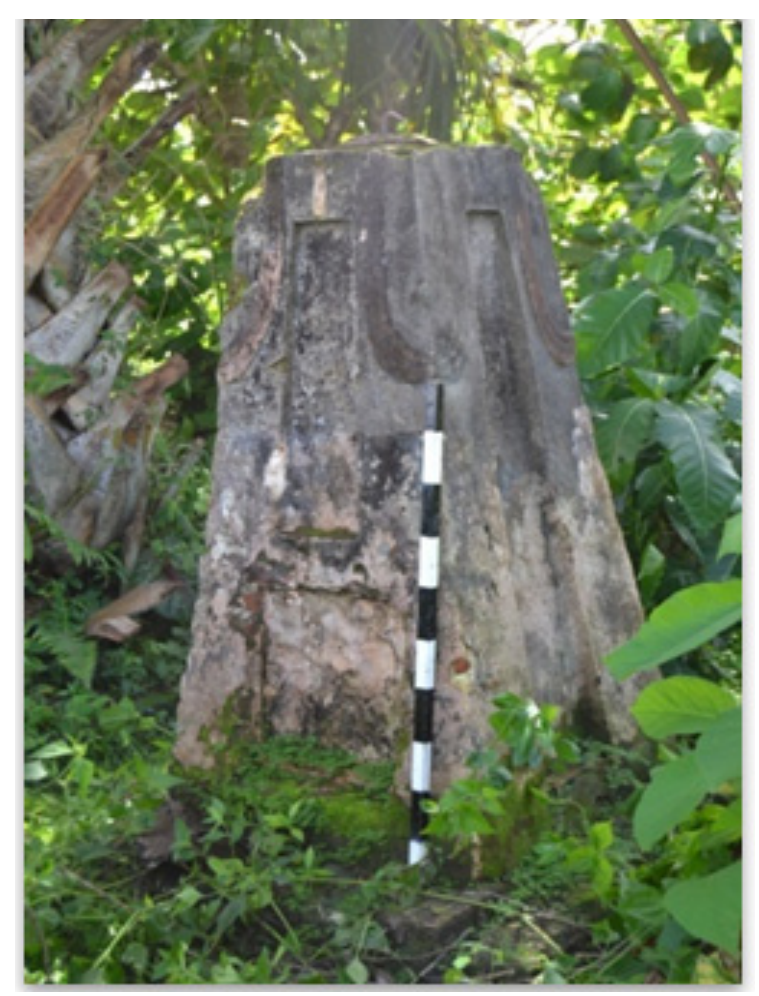

Gambar 12: Salah satu makam yang ada di kerkhof Hila

(Sumber: Tim Penelitian Balai Arkeologi Ambon, 1997) dua tipe makam Eropa yaitu tipe tegak dan tipe horizontal, tipe makam tegak juga memiliki dua variasi yaitu makam dengan ukuran lebih kecil yaitu tinggi $150 \mathrm{~cm}$ dengan ukuran tebal berbentuk persegi yaitu 50 x $50 \mathrm{~cm}$. Makam dengan ukuran kecil ini tampak lebih sederhana karena tidak memiliki hiasan. Sementara itu, makam kedua dengan ukuran lebih besar yaitu tinggi $150 \mathrm{~cm}$ serta ukuran tebal berbentuk persegi pada bagian dasar yaitu $80 \times 80 \mathrm{~cm}$ dan $50 \times 50 \mathrm{~cm}$ pada bagian puncak. Terdapat hiasan pada bagian puncak yaitu setiap sisi sudut memiliki motif menyerupai selendang. Tipe lain pada kompleks makam ini adalah tipe horizontal dengan ukuran 150 x 50 $\mathrm{cm}$. Makam-makam yang ada di lokasi ini tidak dapat diidentifikasi karena tidak ada adanya inskripsi yang dapat memberi informasi tentang orang-orang yang dimakamkan.

\section{Sumur Tua}

Lokasi sumur tua ini berada di belakang lokasi gereja tua Hila yang berjarak $\pm 50 \mathrm{~m}$ arah barat gereja tua dan 100 meter arah selatan Benteng Amsterdam. Masyarakat setempat menyebut sumur ini dengan "Sumur Rumphius", hal ini tidak lepas dari sejarah kehadiran Georgius Everhardus Rumphius salah seorang pegawai Pemerintah Belanda yang pernah bertugas di Hila. Selain sebagai pegawai pemerintah, Rumphius juga mengabdikan hidupnya dengan mendalami berbagai bidang dengan memberikan catatan laporan tentang berbagai hal diantaranya ilmu alam, sejarah, dan berbagai peristiwa semasa hidupnya termasuk bencana tsunami yang pernah melanda Pulau Ambon pada abad ke-17.

\section{Kronologi Benteng Amsterdam}

Berdasarkan sumber-sumber sejarah, wilayah pesisir utara Pulau Ambon merupakan destinasi awal bangsa Eropa dalam upaya pencarian komoditi di Kepulauan Rempah-Rempah. 


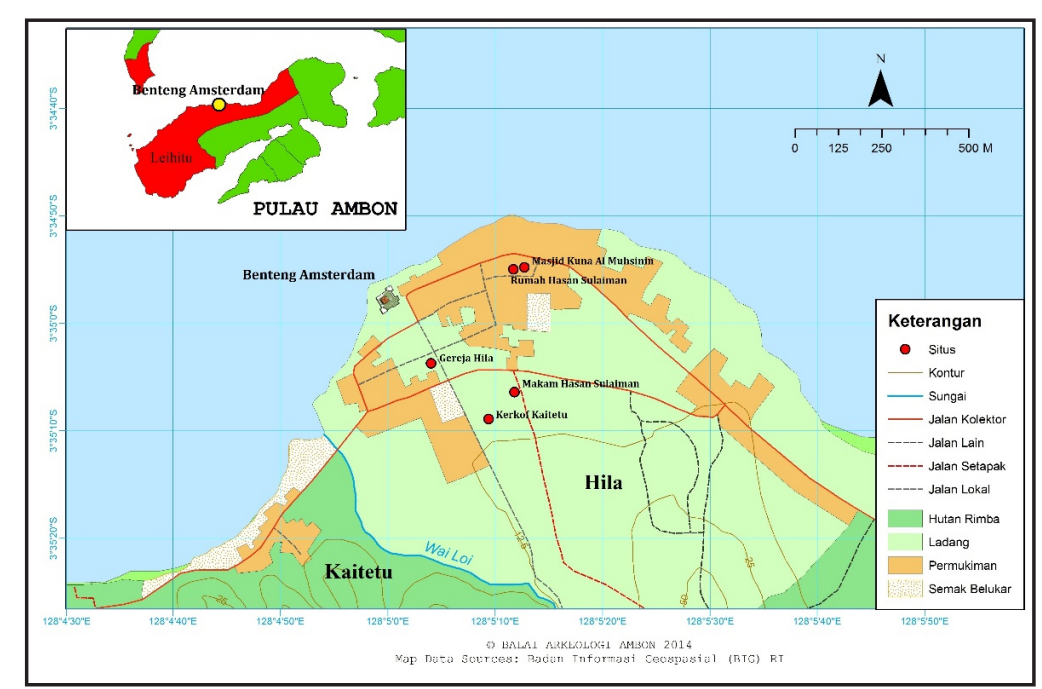

Gambar 13: Peta Situs Benteng Amsterdam dan Sebaran Data Arkeologi di Wilayah Hila-Kaitetu (Sumber: Badan Informasi Geospasial (BIG) RI dan dimodifikasi oleh Penulis dan Tim Pemetaan Balai Arkeologi Ambon, 2013)

Persentuhan awal ini tidak lepas dari munculnya sebuah kerajaan yaitu Kerajaan Tanah Hitu di wilayah ini. Jauh sebelum kedatangan bangsa Eropa, Kerajaan Tanah Hitu telah melakukan kontak dengan para pedagang-pedagang Nusantara maupun pedagang-pedagang Asia lainnya.

Lokasi geografis Pulau Ambon dipandang sangat strategis karena menghubungkan dua pusat produksi rempahrempah yaitu Kepulauan Banda untuk komoditi pala dan Pulau Ternate untuk komoditi cengkih. Disamping itu, perubahan situasi politik di wilayah Kepulauan Maluku di Ternate, Ambon, dan Kepulauan Banda menyebabkan wilayah ini semakin berperan strategis dalam perebutan hegemoni perdagangan rempah-rempah oleh bangsa Eropa. Dalam upaya perebutan hegemoni ini, kekuatan militer menjadi faktor penting menguasai suatu wilayah. Oleh karena itu, dalam setiap kunjungan awalnya, bangsa Eropa selalu berupaya mendirikan sebuah benteng pertahanan. Tentu saja, alasan utama yang dianggap pertimbangan penting adalah fungsi pos perdagangan yang kemudian berkembang menjadi pos pertahanan.
Berbagai catatan awal kedatangan Portugis di wilayah ini menyebutkan bahwa orang-orang Portugis berupaya membentuk komunitas di pesisir utara Pulau Ambon. Catatan ini diantaranya menyebut toponim Sawahtelu di ujung timur pesisir utara Pulau Ambon sebagai daerah permukiman orang-orang Portugis. Demikian halnya yang menyebut bahwa pada saat kedatangan orang-orang Belanda, mereka telah mendirikan sebuah benteng yaitu Kastel Van Verre, di sebuah lokasi yang dekat dengan benteng Portugis. Perubahan politik kemudian terjadi di wilayah ini, dimana Belanda berhasil menggantikan kekuasaan Portugis.

Berbagai sumber terkait dengan sejarah pendirian Benteng Amsterdam menyebut pada awalnya benteng ini merupakan benteng milik bangsa Portugis. Namun, karena situasi politik dengan Kerajaan Tanah Hitu saat itu, benteng ini kemudian ditinggalkan oleh Portugis dan lebih memilih Jazirah Leitimor sebagai pusat kekuasaan. Hal ini dimanfaatkan oleh Belanda yang kemudian menjalin hubungan dengan Kerajaan Tanah Hitu untuk merebut kekuasaan Portugis pada tahun 1605. 
Setelah keberhasilan Belanda menguasai wilayah Maluku, dan seiring dengan pendirian kongsi dagang mereka yaitu VOC, Belanda kemudian menjadikan wilayah ini sebagai salah satu pos perdagangan. Hal ini tampak dalam sebuah dokumentasi kuno yang menggambarkan keberadaan sebuah pos perdagangan di Hila pada tahun 1629. Pada masa pemerintahan Gubernur Gerard Demmer, pos perdagangan ini kemudian dibangun sebagai Blokhuis yang dilengkapi fungsi pertahanan pada tahun 1637. Selanjutnya, pada tahun 1642 yaitu masa Pemerintahan Gubernur Arnold de Vlaming, bangunan berupa blokhuis ini kemudian diperkuat dengan dinding dan bastion sehingga menampakkan bentuknya sekarang ini. Penguatan fungsi pertahanan ini tidak lepas dari situasi politik pada saat itu, dimana masyarakat Hitu mengadakan perlawanan terhadap kekuasaan Belanda di Pesisir Utara Pulau Ambon. Pusat pertahanan tradisional masyarakat Hitu saat itu adalah Benteng Wawani dan Benteng Kapahaha.

Sumber sejarah terkait dengan kronologi Benteng Amsterdam dapat ditelusuri berdasarkan beberapa dokumentasi kuno yang menggambarkan situasi benteng. Dokumentasi ini diantaranya memiliki angka tahun 1629, 1724, 1857, dan 1920-an. Dokumentasi tahun 1629 bersumber dari buku kumpulan peta kuno "Grote Atlas van de Verenigde Oost-Indische Compagnie deel 3 : Indische Archipel en Oceanie" yang disusun oleh Arend de Roever dan Bea Brommer tahun 2008. Dokumentasi tahun 1724 bersumber dari Francois Valentijn yang dimuat dalam buku "Forts in Indonesia" yang diterbitkan oleh Kementerian Pendidikan dan Kebudayaan pada tahun 2012. Sementara itu, dokumentasi tahun 1857 merupakan koleksi pribadi Hans Bonke yang diperoleh pada tahun 2007. Dokumentasi tahun 1920-an adalah sebuah foto hasil inventarisasi bangunan kolonial yang dilakukan oleh V.I. Van de Wall yang diterbitkan pada tahun 1928.

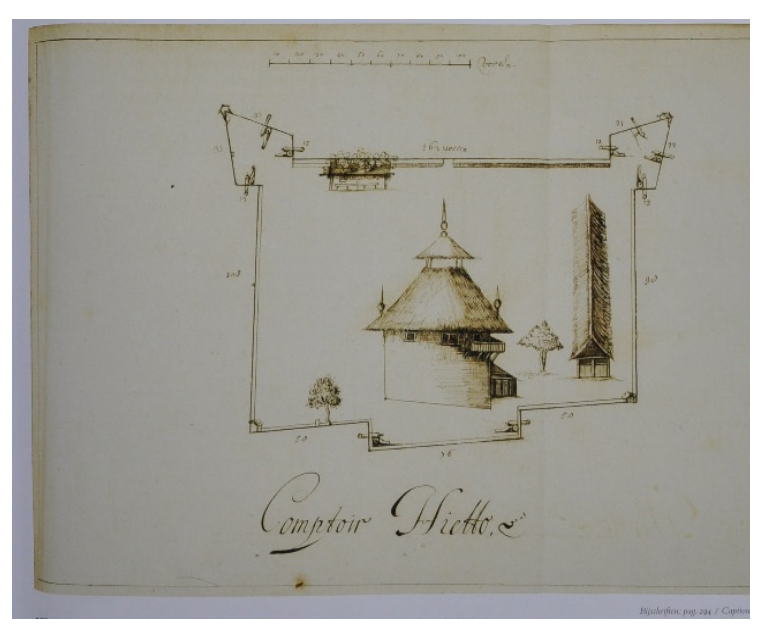

Gambar 14: Dokumentasi kuno yang menampilkan denah awal Benteng Amsterdam di Hila-Kaitetu (Sumber: Forts in Indonesia, 2012)

Berdasarkan interpretasi terhadap dokumentasi kuno yang memiliki angka tahun 1627, tampak bahwa pada awalnya pos perdagangan ini merupakan bangunan non-permanen dimana material utama yang digunakan terbuat dari kayu dan bambu. Unsur-unsur bangunan yang tampak dalam dokumentasi tersebut adalah Blokhuis yang terdapat di tengah-tengah, kemudian dua bangunan non-permanen berbentuk persegi panjang dengan ukuran yang cukup besar dan sebuah bangunan berbentuk persegi dengan ukuran yang lebih kecil. Unsur-unsur bangunan ini kemudian dikelilingi oleh pagar (palisade) berbentuk persegi, pada kedua sudut bagian atas dilengkapi dengan bastion. Dokumentasi ini sendiri tidak menampilkan petunjuk arah mata angin sehingga tidak diketahui orientasi bangunan. Jika mengamati dokumentasi ini, tampak sangat berbeda dengan denah dasar Benteng Amsterdam saat ini. Gambaran yang terdapat pada dokumentasi tersebut kedua bastion ditempatkan sejajar. Sementara kondisi saat ini, terdapat dua bastion yang ditempatkan secara diagonal yaitu sudut timur laut dan barat daya. Kedua bastion ini sendiri diposisikan pada arah orientasi yang berbeda yaitu bastion timur laut mengarah ke laut, dan bastion barat daya mengarah ke darat. 


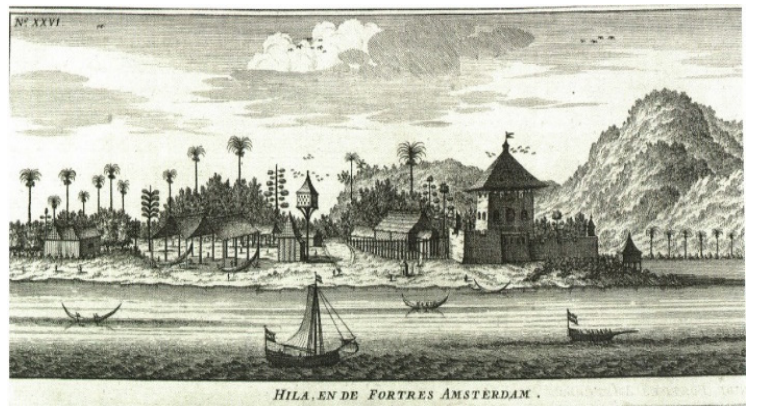

Gambar 15: Gambar yang menampilkan situasi Benteng Amsterdam pada abad ke-18 oleh Francois Velentijn (Sumber: A. Roever dan B. Brommer, 2008).

Sementara itu, dokumentasi kuno yang bersumber dari Francois Valenteijn (1724), menampilkan situasi benteng yang mulai tampak kompleks dengan beberapa bangunan. Diantara bangunan-bangunan tersebut, Blokhuis yang merupakan bangunan utama dibuat dari bahan yang lebih permanen demikian pula dengan dinding benteng yang mengelilingi bangunan Blokhuis. Bangunan non-permanen tampak pada sisi timur benteng. Jika memperhatikan beberapa bangunan non-permanen tersebut, tampak jelas bahwa situasi saat itu telah kondusif sehingga memungkinkan bagi Belanda untuk menempatkan bangunan di luar kompleks benteng.

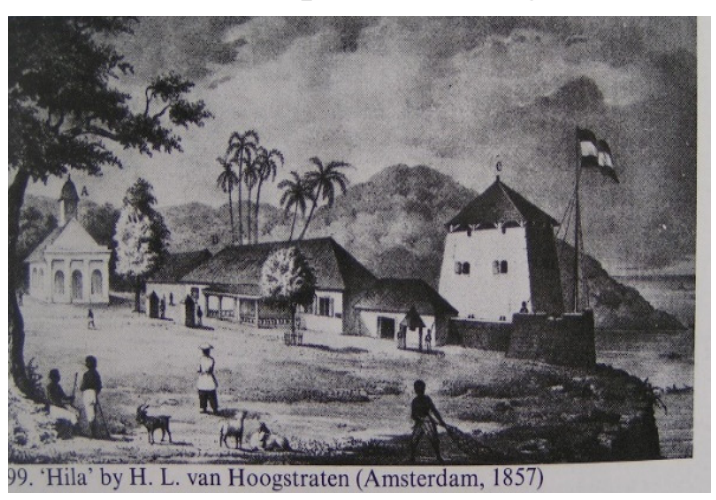

Gambar 16: Situasi Benteng Amsterdam sekitar abad ke-19

(Sumber: Repro dokumentasi pribadi Hans Bonke)

Dokumentasi kuno yang memiliki angka tahun 1857 lebih kompleks dengan adanya beberapa bangunan permanen tambahan di luar kompleks benteng. Unsur-unsur bangunan yang terdapat dalam dokumentasi tersebut yaitu; bangunan blokhuis dan sebuah bangunan persegi panjang ditambah dengan dua bangunan sayap di sisi kiri dan kanan. Ketiga bangunan ini menyatu dengan dinding benteng bagian depan, bangunan sayap pada sisi kiri bangunan persegi merupakan pintu gerbang. Bangunan lain yang tampak dalam dokumentasi tersebut adalah sebuah bangunan dengan empat pilar pada bagian depan dan sebuah menara pada bagian atas bangunan. Unsur benteng yang tampak pada dokumentasi ini selain gerbang dan dinding juga tampak salah satu bastion yang kemungkinan merupakan bastion timur laut.

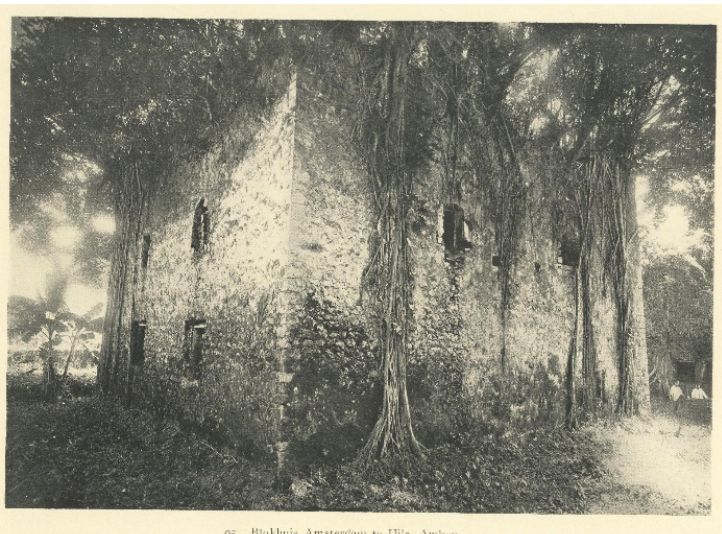

Gambar 17. Foto yang menampilkan kondisi Benteng Amsterdam sekitar awal abad ke-20 (Sumber: Victor Ido van de Wall, 1928).

Sementara itu, dokumentasi kuno yang memiliki angka tahun 1920-an hanya memuat bangunan inti yaitu blokhuis yang saat itu dalam kondisi rusak parah dan tampaknya blokhuis ini hanya berupa puing-puing bangunan. Tampak jelas dalam foto tersebut dinding-dinding blokhuis telah ditumbuhi tanaman merambat dan akar-akar pohon telah menempel di dinding bangunan. Hal ini sekaligus menjelaskan bahwa pada awal abad ke-20, benteng Amsterdam tidak lagi difungsikan oleh Pemerintah Belanda, baik fungsi perdagangan, fungsi pertahanan maupun fungsi lainnya.

Sementara itu, data arkeologi yang dapat menjelaskan kronologi hunian di Benteng Amsterdam adalah temuan fragmen keramik baik yang ada di permukaan 
maupun yang ada di bawah permukaan tanah. Berdasarkan analisis kronologi keramik diketahui bahwa keramik yang dominan adalah keramik-keramik Cina yang berasal dari Dinasti Qing dengan pertanggalan sekitar abad ke 18 hingga abad ke 20. Demikian pula keramikkeramik yang berasal dari Eropa yang menunjukkan pertanggalan abad ke $19-$ 20. Sementara itu, fragmen keramik yang berasal dari periode sebelumnya yaitu keramik Dinasti Ming Swatow dan Vietnam menunjukkan bahwa okupasi terhadap situs ini mulai dilakukan sejak abad ke-16. Temuan-temuan lain yang memberi gambaran tentang periode hunian situs ini adalah temuan berupa pipa tembakau dan fragmen botol. Temuan-temuan ini memberi indikasi hunian oleh orang-orang Eropa yang membawa kebiasaan dalam kehidupan sehari-hari mereka. Khusus untuk temuan fragmen botol, ciri-ciri menunjukkan bahwa botol-botol ini merupakan produksi Eropa sekitar abad ke-19.

\section{Fungsi dan Peran Benteng Amster- dam}

Fungsi dan peran benteng seringkali mengalami pergeseran dari sekedar simbol pertahanan menjadi pusat aktivitas dan interaksi manusia. Berbagai aktivitas yang terjadi di dalam benteng bukan hanya terbatas pada aktivitas peperangan, namun juga berbagai aspek kehidupan termasuk ekonomi dan budaya. Hal ini mempengaruhi fungsi dan peran benteng menjadi pusat kehidupan sosial dan akhirnya menjadi pusat administrasi dan pemerintahan. Pergeseran fungsi dan peran dari institusi keamanan menjadi institusi pemerintahan terjadi ketika benteng dikelola oleh sekelompok orang yang terorganisir dalam suatu lembaga khusus, dengan wewenang politik dan ekonomi. Lembaga inilah yang akhirnya memiliki sistem administrasi, hirarki yang terwujud dalam birokrasi, korps yang menopang status dan wewenangnya (Marihandono, 2008:5).
Dengan demikian, benteng sejatinya merupakan bangunan pertahanan, namun dalam setiap perkembangannya bangunan benteng memiliki beragam fungsi. Secara umum, benteng-benteng Kolonial di Indonesia dibangun ketika Portugis, Spanyol, Belanda, dan Inggris mulai bersentuhan dengan wilayah-wilayah yang kaya akan sumberdaya alam yang menjadi incaran komoditas perdagangan mereka. Dengan demikian, selain fungsi pertahanan, fungsi perdagangan juga merupakan fungsi awal sebuah benteng. Hal ini juga terjadi di wilayah pesisir utara Pulau Ambon atau Jasirah Leihitu, dimana Belanda membangun benteng Amsterdam untuk difungsikan sebagai pusat pertahanan, perdagangan, permukiman, dan pemerintahan.

Jika mengamati analisis keruangan berdasarkan hasil pengupasan struktur yang menampakkan berbagai ruang yang menempel di dinding timur dan selatan benteng. Fungsi-fungsi ruang tampak di dinding sisi timur yang kemungkinan difungsikan sebagai gerbang, kantor, dan pos jaga. Fungsi ruang berikutnya tampak di dinding sisi selatan benteng yang kemungkinan difungsikan sebagai barak militer, tempat tinggal pejabat Belanda, kamar mandi dan dapur.

Seiring dengan perkembangan kebutuhan saat itu, Belanda kemudian mengembangkan fungsi benteng tersebut. Tidak hanya benteng sebagai bangunan utama, namun juga pembangunan berbagai sarana dan prasarana ditambahkan di luar benteng. Kondisi keamanan juga menjadi pertimbangan utama dimana orientasi bangunan turutan dalam benteng mulai diarahkan ke luar benteng. Hal ini diketahui berdasarkan interpretasi terhadap dokumentasi kuno yang menggambarkan situasi benteng akhir abad ke-19. Pembangunan sebuah gereja yang dibangun sekitar abad ke-18 serta keberadaan sumur di sebelah barat bagunan gereja, juga memberi informasi bahwa fungsi permukiman dan religi mulai diarahkan di kawasan sekitar 
benteng yaitu bagian selatan benteng. Hal ini sekaligus menunjukkan bahwa fungsi permukiman kawasan sekitar benteng semakin mapan dengan keberadaan berbagai fasilitas di luar benteng.

Sebagaimana telah diuraikan sebelumnya bahwa Benteng Amsterdam pada awalnya dibangun sebagai sebuah pos perdagangan, dan karena pertimbangan keamanan maka bangunan ini diperkuat dan berfungsi penuh sebagai benteng pertahanan. Meski demikian, dalam perkembangan selanjutnya setelah situasi keamanan lebih kondusif fungsi awal sebagai pos perdagangan kemudian lebih dominan. Berbagai catatan administrasi tentang perdagangan komoditi cengkih di wilayah Pulau Ambon dan sekitarnya pada abad ke-17 (1620 hingga 1695) menunjukkan bahwa wilayah pesisir utara Pulau Ambon memberi kontribusi besar bagi perdagangan cengkih VOC (Knaap, 2004: 297; Mansyur, 2012: 69). Keberhasilan perdagangan ini didukung dengan pengawasan yang ketat oleh VOC melalui ekspedisi hongitochten. Ekspedisi-ekspedisi besar yang dikirim oleh VOC untuk mengawasi produksi cengkih ini diantaranya; tahun 1625 dan 1637 di wilayah Hoamoal (de Graaf, 1977: 43-46; Knaap, 2003: 178; Straver, 2011: 70)

Dari aspek pemerintahan, kebijakan monopoli ini didukung oleh sistem administrasi pemerintahan yang membagi beberapa wilayah administratif di Pulau Ambon dan sekitarnya. Khusus untuk wilayah pesisir utara Pulau Ambon terbagi atas dua wilayah yang disebut regio yaitu regio Hitu dan Larike. Regio Hitu dipusatkan di Benteng Amsterdam yang ada di Hila yang membawahi 21 Drop atau desa (Knaap, 2004: 351; Mansyur, 2012: 70). Dalam konteks tata niaga inilah, wilayahwilayah yang berada di bawah regio Hitu kemudian mensuplai produksi cengkih kepada VOC. Fungsi Benteng Amsterdam sebagai pos perdagangan tampak jelas di sini yaitu sebagai pusat pengumpul bagi
VOC untuk wilayah regio Hitu. Bentuk bangunan berupa blokhuis yang diperkuat dengan dinding pertahanan menjadikan bangunan ini berfungsi sebagai gudang komoditi yang memiliki sistem pertahanan yang kuat.

Dengan demikian, kebijakan monopoli perdagangan rempah-rempah (cengkih) sejak abad ke-17 hingga akhir abad ke-19 yang diterapkan oleh Belanda saat itu serta didukung dengan sistem tata niaga sangat berpengaruh terhadap perkembangan wilayah di pesisir utara Pulau Ambon khususnya di Hila. Hal ini dapat diketahui berdasarkan interpretasi terhadap beberapa dokumentasi kuno, dimana pada awalnya bangunan yang ada hanya bangunan non-permanen yang difungsikan sebagai pos perdagangan dan berkembang menjadi sebuah kompleks bangunan yang tidak hanya berfungsi sebagai pusat perdagangan tetapi juga pusat pertahanan, pemerintahan, religi dan permukiman. Interpretasi terhadap dokumentasi kuno ini juga jelas menunjukkan bahwa ketika perdagangan cengkih tidak lagi memberi keuntungan yang baik (setelah sistem monopoli pada tahun 1865 dihapus), wilayah ini tidak lagi mendapat perhatian. Hal ini setidaknya dapat diketahui dari dokumentasi yang menggambarkan kondisi Benteng Amsterdam pada tahun 1920-an yang tidak terawat.

Sejak keberhasilan Belanda menguasai wilayah ini, para pejabat Belanda secara bergantian bertugas dan ditempatkan di Benteng Amsterdam. Salah seorang pejabat perwakilan pemerintah Belanda yang pernah bertugas di Benteng Amsterdam adalah Georgius Everhardus Rumphius. G.E. Rumphius memulai tugasnya sebagai wakil pemerintah yang ditempatkan di Benteng Rotterdam (Larike) dan beberapa tahun kemudian ditugaskan di Benteng Amsterdam (Hila). Ketertarikannya terhadap ilmu pengetahuan kemudian menjadikan G.E Rumphius terkenal sebagai salah seorang Naturalis yang telah menghasil- 
kan beberapa karya yang memuat tentang kehidupan alam flora dan fauna di Pulau Ambon dan sekitarnya. Salah satu karyanya juga memuat tentang sebuah peristiwa bencana alam yang saat ini dikenal dengan Tsunami yang melanda negerinegeri di wilayah pesisir utara Pulau Ambon. Karya ini bahkan merupakan karya pertama di dunia yang menggambarkan kondisi wilayah ini setelah diterjang bencana tsunami.

\section{KESIMPULAN}

Kehadiran bangsa Eropa di wilayah pesisir utara Pulau Ambon menjadikan wilayah ini sebagai salah satu wilayah yang mengalami kontak awal dengan bangsa Eropa di Nusantara. Tercatat bahwa kehadiran bangsa Portugis pada tahun 1512, tidak lama setelah mereka menaklukkan Malaka sebagai Bandar niaga di wilayah Asia Tenggara. Meski awalnya merupakan sebuah insiden, kehadiran mereka di tengah-tengah masyarakat Tanah Hitu tetap merupakan catatan awal kehadiran Portugis di Kepulauan Maluku. Sejak saat itu, bangsa Eropa lain termasuk Belanda dan Inggris mulai mengenal Kepulauan Maluku sebagai penghasil utama cengkih dan pala.

Melalui sistem monopoli yang didukung jaringan perbentengan, Belanda berhasil mendapatkan keuntungan besar dari perdagangan cengkih di wilayah Maluku. Pada awalnya, benteng-benteng dibangun sebagai pos perdagangan termasuk salah satunya adalah Benteng Amsterdam di Hila. Keberhasilan Belanda memantapkan situasi politik dan keamanan di wilayah pesisir utara Pulau Ambon sekaligus memantapkan fungsi perdagangan (gudang komoditi) benteng Amsterdam. Fungsi perdagangan benteng ini berkembang seiring dengan fungsi pertahanan, khususnya saat menghadapi perlawanan pribumi pada pertengahan abad ke-17.
Variabilitas temuan arkeologi yang berkorelasi dengan periode kolonial di lokasi penelitian didominasi oleh temuan monumental, berupa benteng, gereja, sumur, kerkhof, rumah tinggal dan masjid. Terkait kronologi Benteng Amsterdam yang awal merupakan pos perdagangan dan dibangun kembali dengan struktur yang lebih permanen serta tambahan dinding dan bastion pada tahun 1637. Selain itu, terungkap pula fungsi dan peran Benteng Amsterdam serta perubahan peran wilayah dalam konteks administrasi pemerintahan Belanda yang mempengaruhi pengembangan tata ruang Benteng Amsterdam. Dalam konteks pengembangan tata ruang, benteng ini mengalami beberapa kali renovasi yang tampak pada sisi dinding timur (gerbang) dan sisi dinding selatan. Jika membandingkan ketebalan dinding pada bastion timur laut, tampaknya dinding timur telah mengalami perubahan seiring dengan pembangunan ruang-ruang yang menempel di dinding timur. Demikian halnya dinding selatan terdapat ruang-ruang yang menempel pada dinding tersebut.

Hasil penelitian juga menunjukkan bahwa terjadi pergeseran fungsi dan peran benteng Amsterdam bagi daerah sekitarnya. Pergeseran fungsi sebagaimana telah disebutkan di atas, bahwa benteng Amsterdam pada awalnya berfungsi sebagai pos perdagangan, namun dalam perkembangannya menjadi pusat pertahanan VOC menghadapi perlawanan pribumi. Dalam perkembangan selanjutnya, setelah situasi politik dan keamanan lebih kondusif benteng ini berfungsi sebagai gudang komoditi. Selanjutnya, pergeseran peran benteng ini terkait dengan periode perdagangan cengkih yang dikembangkan oleh VOC di wilayah ini. Sekitar abad ke-17, Benteng Amsterdam berperan sebagai pusat perdagangan cengkih untuk wilayah bagian timur pesisir utara Pulau Ambon. Namun, peran ini mengalami pergeseran seiring dengan menurunnya perdagangan cengkih sekitar abad ke-19 terlebih ketika kebijakan monopoli cengkih dihapuskan oleh Pemerintah Belanda pada tahun 1865 . 


\section{Ucapan Terima Kasih}

Terima kasih penulis ucapkan kepada Cheviano E. Alputila yang telah memilih temuan keramik hasil ekskavasi di Situs Amsterdam sebagai sampel yang diajukan dalam sebuah kesempatan pelatihan (workshop) analisis keramik di Balai Arkeologi Ambon pada tahun 2013. Ucapan terima kasih juga penulis sampaikan kepada Prof. (Ris.) Naniek Harkantiningsih yang telah bersedia memberikan pelatihan analisis keramik di Balai Arkeologi Ambon sehingga analisis keramik terhadap temuan di Situs Benteng Amsterdam dapat dilakukan dengan baik.

$* * * * *$

\section{DAFTAR PUSTAKA}

Abdurachman, Paramita. R. (1973). Pening galan-Peninggalan Yang Berciri Portugis di Ambon. Bunga Rampai Sejarah Maluku. Jakarta: Lembaga Penelitian Sejarah Maluku.

Abdurachman, Paramita. R. (2008). Bunga Angin Portugis di Nusantara: Jejak-Jejak Kebudayaan Portugis di Indonesia. Jakarta: Yayasan Obor.

Bonke, Hans. (2010). European Forts in the Indonesian Archipelago (Nusantara). Inventory and Identification Forts in Indonesia, 32-45. Jakarta: Pusat Dokumentasi Arsitektur; Direktorat Peninggalan Purbakala Kementerian Kebudayaan dan Pariwisata; PAC Architects and Consultants.

de Graaf. (1977). Sejarah Ambon dan Maluku Selatan. Alih Bahasa oleh Drs. Frans Rijoly, De Geschiedenis van Ambon en de Zuid Molukken.

Harkantiningsih, N., Sarjiyanto, L.H. Inagurasi, dan D. Rudatin. (2010). Kajian Kewilayahan Pengaruh Kolonial di Nusantara: Penelitian dan Pengembangan. Evaluasi Hasil Penelitian Arkeologi (EHPA). Yogyakarta: Pusat Penelitian dan Pengembangan Arkeologi Nasional.
Inagurasi, L.H. (2011). Benteng Oranje di Ternate: Penggunaannya Abad ke-17-20 M. Kalpataru Majalah Arkeologi, 20(1), 2136.

Knaap, G. (2003). Headhunting, Carnage and Armed Peace in Amboina, 1500-1700. Journal of the Economic and Social History of the Orient, 46(2), 165-192.

Knaap, G. (2004). Kruidnagelen en Christenen de VOC en de bevolking van Ambon 16561696. Leiden: Koninklijk Instituut voor Taal-, Land-en Volkenkunde (KITLV).

Leirissa, R.Z., et. al. (1973). Kebijaksanaan VOC untuk Mendapatkan Monopoli Perdagangan Cengkeh di Maluku Tengah antara Tahun-Tahun 1615-1652. Bunga Rampai Sejarah Maluku. Jakarta: Lembaga Penelitian Sejarah Maluku.

Manusama, Z.J. (1973). Sekelumit Sejarah Tanah Hitu dan Nusa Laut serta Struktur Pemerintahannya Sampai Pertengahan Abad Ketujuhbelas. Bunga Rampai Sejarah Maluku. Jakarta: Lembaga Penelitian Sejarah Maluku.

Mansyur, Syahruddin. (2014). Sistem Perbentengan dalam Jaringan Niaga Cengkih Masa Kolonial di Maluku. Kapata Arkeologi, 10(2), 85-98.

Mansyur, Syahruddin. (2012). Peran Wilayah Negeri Larike Pada Masa Kolonial. Kapata Arkeologi, 8(2), 65-72.

Marihandono, Joko. (2008). Perubahan Peran dan Fungsi Benteng dalam Tata Ruang Kota. Wacana: Jurnal Ilmu Pengetahuan Budaya, 10(1)

Ricklefs. M.C. (2010). Sejarah Indone sia Modern: 1200-2008. Jakarta: Serambi

Rumphius., G.E. tanpa tahun. Sejarah Ambon. Alih Bahasa Oleh Frans Rijoly. De Ambonsche Historie.

Soekiman, Djoko. (1997). Seni Bangunan Gaya Indis, Pemilikan, Pelestarian, dan Pemanfaatannya, Diskusi Ilmiah Arkeologi VII. Yogyakarta: Ikatan Ahli Arkeologi Indonesia Komda D.I. Yogyakarta.

Straver, H. (2011). Vensters op de Molukse ge schiedenis 1450-1950. Utrecht: Landelijk Steunpunt Educatie Molukkers. 
Sumalyo, Yulianto, (1999). Ujung Pandang Perkembangan Kota dan Arsitektur Pada Akhir Abad 17 Hingga Awal Abad 20. Panggung Sejarah: Persembahan kepada Prof. Dr. Denys Lombard, Ecole Francaise d'extreme-Orient, Pusat Penelitian Arkeologi Nasional. Jakarta: Yayasan Obor Indonesia.

Tim Penelitian. (2012). Menelusuri Jejak Niaga Cengkih Masa Kolonial di Pesisir Utara Pulau Ambon. Laporan Penelitian Arkeologi. Ambon: Balai Arkeologi Ambon. Tidak terbit.

Tim Penelitian. (2013). Ekskavasi Situs Benteng Amsterdam di Kecamatan Leihitu Kabupaten Maluku Tengah. Laporan Penelitian Arkeologi. Ambon: Balai Arkeologi Ambon. Tidak terbit.

\section{Sumber internet:}

www.amalatu.zoomshare.com. Hikayat Tanah Hitu. Diakses tanggal 12 Mei 2011.

\section{Sumber Dokumentasi Kuno:}

Ministry of Education and Culture Republic of Indonesia, 2012. Forts in Indonesia. Jakarta: Ministry of Education and Culture Republic of Indonesia.

Roever, A.de. et.al. 2008. Grote Atlas van de Verenigde Oost-Indische Compagnie deel 3: Indisvhe Archipel en Oceanie. Zierikzee: Asia Maior.

Wall, Victor Ido van de. 1928. de Nederlandsche Oudheden in de Molukken. Gravenhage: Martinus Hijhoff. 